By MARK SCHORER

\title{
The Harassed Humanities
}

W HeN Sinclair Lewis, a brash young man, was a senior in Yale College, he seriously considered continuing his studies in the graduate school and obtaining the Ph.D. in English literature. But he suddenly changed his mind and concluded his Yale diaries with the observation that "Humanity outweighs the Humanities." Earlier in that year, in a similar mood, he had copied out as his motto the old Latin tag that nothing that is human was alien to him. And here we have, I think, a rather tidy parable. The world created in the novels of Sinclair Lewis is, essentially, an inhuman world. We cannot easily assume, to be sure, that had the young man gone on in pursuit of the Ph.D. in literature, he would, as a practicing artist, have been concerned to present a world in which humane values played a more central role; indeed, he might have become no novelist at all but merely an undistinguished professor. And yet, I wonder. ... If he had truly imaginative powers-was destined, I mean to say, to be a novelist, no matter what else happened to him-and if his imagination was capable of humanistic training, would he have been so intent on presenting human experience at such a brutish level as we discover in novels like Main Street, Babbitt, The Man Who Knew Coolidge, Elmer Gantry? Humanity, he declared, was his concern; but if we open any of these novels almost any-

Dr. Schorer is Professor of English, University of California, Berkeley. The original of this paper, now slightly revised, was presented at the membership meeting of ACRL, July 15, 1958, San Francisco. Copyright Mark Schorer 1959. where what we discover is-precisely-a world of people almost totally untouched by the humanities.

The world of Sinclair Lewis rests upon two observations: the standardization of manners in a business culture, and the stultification of morals under middleclass convention. All his critical observations are marshalled in support of these propositions, and his portrait of the middle class rests entirely upon them.

This is an extremely narrow perspective, but its narrowness projects a very sharply defined image. "Life dehumanized by indifference or enmity to all human values-that is the keynote of both Gopher Prairie and Zenith," wrote T. K. Whipple thirty years ago in what remains one of the very few critical essays on Lewis. " . . Nowhere does this animosity show itself more plainly than in hostility to truth and art. The creed of both towns is the philosophy of boosting, a hollow optimism and false cheeriness which leads directly to hypocrisy, as in making believe that business knavery is social service. Toward ideas likely to break this bubble of pretense the people are bitterly opposed; toward new ideas they are lazily contemptuous; toward other ideas they are apathetic... intellectually both are cities of the dead, and in both, the dead are resolved that no one shall live." Dead in the senses as they are in intellect and the affections, these people are horrible ciphers, empty of personality or individual consciousness, rigidly controlled by set social responses; and yet, being dead, together they do not form a society in any real sense, but only a group, a group which at once controls them and protects them from the horrors of their own emptiness. 
Their group activities, whether as families, as clubs, as friends, are travesties of that human interchange that makes for meaningful social activities: conversation is buffoonery, affection is noise, gaiety is pretense, business is brutal rush, religion is blasphemy. The end result is vacant social types in a nonsocial world. Quite brilliantly Whipple made the observation that Babbitt is set in Hell: "it is almost a perfectly conceived poetic vision of a perfectly . . . standardized hinterland."

The feeblest characters in Main Street and those most quickly routed, are the critics of its society, the discontented. Carol Kennicott's vaporous values are hardly the humanistic opposites of the stultifications of Main Street. The Babbitt who momentarily challenges Zenith does not so much present us with a scale of humane values that we can oppose to the inhumanity of the environment, as he presents us with all the insecurity on which Babbittry, or the environment, rests. On the very fringes of the narrative of Elmer Gantry, among his scores of vicious characters, Lewis permits a few shadowy figures of good to appear, the amiable skeptics who are routed before they are permitted to enter the action, but they are so weak that they present no challenge to EImer, serve only to illustrate the ruthlessness of Elmer's power. The fact that there is never any real opposition of substantial values to "convention," or false values (as there is never any truly individual character to resist the social types), is what makes Lewis' world so blank. In Elmer Gantry we do not have even the earlier fitful glimmerings in the realm of reverie. This is a world of total death, of social monsters without shadow.

Yet you will have observed that one major novel I have not mentioned: this is the climax of our parable. The novel is Arrowsmith, and when we say that in Lewis' world there are no values, we must always except the figures of Doctors Gottleib and Arrowsmith, with their dedication to pure science and disinterested scientific research. This is also the turn of the screw for the humanities.

I have lingered too long, perhaps, with my man. And yet I know of no other figure who could better illustrate our problem than he. This is, I have said, a world devoid of humane values, untouched by the humanities. Invert its every negative and the humanities stand before us-serene and poised, rich in experience and educated in the affections, individual and independent, just and lovely - a goddess. If Sinclair Lewis is my man, it is she who is my lady.

Without quite intending it, I have suggested a sex for the humanities. The absurdity is apparent. By the term "the humanities" one means simply all those studies that try to understand the means by which recording man-there are a number of ways of leaving a recordhas recorded the state of his civilization from the earliest time until this moment. In such a history, neither sex, male nor female, has priority. It is almost certainly true that in this history nothing is more important than the relationship between individual men and women. It is also certainly true that while this history preserves for us all that is heroic and tragic and magnificent in human experience, it does so through preserving for us all that is gracious and gentle, charming, seductive, enchanting - the qualities that one ordinarily associates with woman. I am reminded of an observation by Alfred North Whitehead, when he wrote: "Many an ape man must have snatched up a stone wherewith to hit somebody, either another man or another animal, on the head, without any reflection upon the course of nature beyond the next few minutes. Also he might notice that some stones are better 
than others as lethal weapons, and he might even help them out by chipping them. He is then approaching civilization. But he-or more probably, shehas crossed the great divide, when he puts seeds into a patch of earth and waits for a season." Note: more probab$l y$, she; so perhaps my unwitting attribution of sex is not so mistaken, since I suspect that it was at this moment, too, that the humanities were born. This was the moment when humanity itself discovered the possibilities of creation and, with that, the fact of continuity. Continuity is history or tradition, and civilization is the history of continuous creation. This moment of discovery repeats itself endlessly in human experience, and the individual humanist, the devotee of the humanities, is born whenever he makes the rediscovery.

I have used, too, the word serene, which would seem peculiarly inappropriate to my title, The Harassed Humanities. But, of course, it is not that vast body of wisdom and creative achievement that comprises the humanities, that is harassed today; it is, rather, those of us who serve the humanities, we who call ourselves humanists.

If we are to understand why the humanist is or feels himself to be harrassed in 1959, we must first understand what the humanities are and how they differ from other branches of learning. Conventionally, of course, learning is $\mathrm{di}$ vided into three parts- the sciences, the social sciences, and the humanities. The sciences are dedicated to the analysis and description of structures, including the human structure, and eliminating insofar as possible any personal or personalizing element. The social sciences, striving toward the impersonality of the sciences proper, analyze and describe the structure of society, which is to say, man in his group relationships. Between the two stands psychology, which attempts to use the impersonal method of science to ana- lyze and describe the protean structures of personality itself. The humanities include all that remains; but that whole remainder rests on a single exclusion made by each of the other disciplines: the individual human being. Once this was called his soul, sometimes it is called his character, loosely it is known as his personality, sometimes as his sensibility: whatever it is called, it is that which makes him him and no one else, that which sets him apart from the whole of the biological record of the race, his self, his very self, sets him apart from the whole or any fraction of society, even though, quite obviously, he exists and functions biologically, exists and functions within society. Yet there is a residue that is forever reluctant to submerge itself completely in these functions. This is individual man.

In each of these three areas of learning, the end is the same, of course: knowledge; and in each, knowledge that is as exact as can be. But there are different orders of knowledge, as there are of truth, and I believe that only with the third area, the humanities, may we associate a term that is larger than "knowledge." I mean wisdom. Wisdom cannot be taught. So a young man recently learned when his $\$ 8,000$ law suit against Columbia University for failing to teach him wisdom was thrown out of court. As no one can put a price label on wisdom, so none of the learned disciplines can teach it; but the humanities -which dedicate themselves to an exploration of the accumulated wisdom of the past, whereas both the sciences and the social sciences are almost exclusively concerned with the facts of the presentonly from the discipline of the humanities does wisdom sometimes emerge. The sciences and the social sciences are disciplines of measurement: they measure and their results can be measured. When accuracy, exactitude, and measure- 
ment are scrutinized for their human worth, are scrutinized as values, the humanities are making the scrutiny. The humanities cannot be measured, but they give us the whole measure of man-man, the infinitely various individual.

In our century, individual man willingly or unwillingly threatens to submerge himself at last-in the vast mechanical processes of industry and war and institutions if not in the cosmic holocaust itself. In a recent $\mathrm{BBC}$ address, Goronwy Rees spoke of this queer but characteristic development in modern times, the fate of the individual. He said in part: "If you walk through the picture galleries of Europe ... and if you look at the portraits of men and women of certain centuries, you will see the faces of people who in some way seem to have satisfied every need of their own nature; faces that are proud and passionate and self-assured, in which every feature seems to be moulded by the personality within; and especially if you look at the eyes, they are the eyes of men and women who, beneath all their pride and all their passion, seem to be at peace simply because they are themselves. You may well ask what such faces have to do with us today, and more especially when modern portraits are often, for all their brilliance and beauty, not expressions of personality but abstract constructions of planes and figures and surfaces. The man within seems to have vanished. Is it because he really has vanished or because the artist, for reasons of his own, no longer sees him? It may be that he really has vanished; that we have entered an age when human personality is, as it were, overshadowed by other forces; that the typical figures of our day, a clerk in an insurance office, a businessman directing the activities of a thousand anonymous employees, a highly paid technician whose task in life is to serve an enormously complicated and expensive ma- chine, would have every right to laugh in one's face if one spoke to them of their unique value and infinite potentialities as human beings. Ruskin once said: 'As I go to my work in the British Museum I see the faces of the people become daily more corrupt'; and if you stand in a London underground station during the rush hour you are surprised at the number, not of the living but of the dead." Which reminds one, of course, of T. S. Eliot's lines in The Waste Land-

"Unreal city,

Under the brown fog of a winter dawn,

A crowd flowed over London Bridge, so many,

I had not thought death had undone so many."

The modern death. William James once said that there is very little difference between one man and another, but that what little there is, is important. What little there is is the difference between life and death, between individual living and the death of mass conformity. The humanities know that what little difference there is, is everything, and not for the individual alone, but for the civilization of which he is a functioning part. Emerson saw the connection: "Friendship and association are very fine things" - he wrote- "and a grand phalanx of the best of the human race, banded for some catholic object. Yes, excellent, but remember that no society can ever be so large as one man. He, in his friendship, in his natural and momentary associations, doubles or multiplies himself, but in the hour in which he mortgages himself to two or ten or twenty, he dwarfs himself below the stature of one." The motive of the humanities is to assist every man who will come to them to maintain "the stature of one."

It is, perhaps, the very nobility of this aim when it confronts the social realities of the age that is the source of our harassment. The age that claims most for individuality is in fact the age 
that seems to have left least room for it, that regards it with the least concern; small wonder that the humanities should suffer, that the efforts of the humanist should in most quarters-many of them powerful-be ignored when they are not despised. There are, of course, many ineffectual humanists, just as there are bungling scientists and merely burbling social scientists. One would not claim that all humanists are humane, or that there are no humanists among men of science. To name a great living humanist among the latter one need only mention Robert Oppenheimer, and one may with cause suspect that it was the very humanistic character of this man-the impulse to cultivate the whole of his qualities of intelligence and feeling, the breadth of his interest, the determinedly free inquiry into areas beyond sciencethat brought about his tragic history, which is, in fact, only our disgrace, as it is our loss. The scientific work of the man of science, obscure as it may be to most of us, is not questioned. The work of the social scientist, while generally regarded as being less drastically important, is nevertheless respected and rewarded by public and official support. An enormous grant, for example, supports the well-publicized effort to analyze and describe the sexual behavior of Americans. One might have thought that, except for the workings of the creative artist, the sexual relationship was the subject least susceptible to scientific analysis. Perhaps. Yet even now another large grant supports, in Berkeley, a bureau to assess the creative personality. No, the social sciences do not lack either support or a certain daring initiative. But the humanities, perhaps because they lack a comparable initiative, seem chiefly to be the object of attack. We try to teach languages - the very cornerstone of humanistic inquiry - and perhaps demonstrably have not done a very good job. Even the President, in that incredible prose which seems to bear some mysterious relation to our common speech, complained recently that his teachers in four different foreign languages had failed to teach him any one of them; and his remarks quite properly led one correspondent to the San Francisco Chronicle to inquire, "What about English?" Meanwhile, professional "educationists," both in the colleges and in the high schools, resist the institution of really adequate language training and urge instead the centrality of courses in driver education, home-making, hair styling, the use of deodorants, "marriageable you," and other forms of "life adjustment" that may succeed in manicuring the "personality," as it is called, but leave untouched-or debauched-the human mind. We try to teach an understanding and inculcate an appreciation of the great creative forms of civilized man: literature, painting, sculpture, architecture, music, and so on; and we are challenged with the unanswerable question, "What good will that do?" As for those larger aims that an experience of the humane arts are to achieve-independence of mind and judgment, free inquiry into any area of human enterprise, a sense of history and with it a delight in the endless variety of human observation and experience, tolerance of differences and sensitivity to the nuances of individuality, the "educated heart"-all these seem more and more suspect to more and more people, as the great majority of us desires above all to slide into the vast anonymity of "the other directed," in David Riesman's now famous phrase. And the final goal, which is the sum of all these, maintaining "the stature of one" in every educated man and woman, seems to become the merest fantasy in the presence of all the problems that command our immediate attention in the post-Sputnik world: who 
can afford to read Homer when we haven't learned to retrieve our missile mouse? And there are, of course, many pressing immediate problems beyond that one posed by our sense of the threat of Russian supremacy: recession and unemployment and the stock market, cerebral palsy and leukemia, juvenile delinquency, political contests and political corruption, narcotics and alcoholism, mental health-these are but a few. But suppose science and social science solved them all: that would still leave the humanities - and only the humanities - to ask the question: for what end did you solve them? For what profiteth it a man if he gain the whole world and ...?

No one is asking that question very loudly today. The sense of urgency in solving measurable problems leads the public to give its vigorous support to the sciences and the social sciences and almost none to the humanities. If you will examine the bulletin on graduate scholarships in the University of California-or, I daresay, throughout the United States in any but possibly one or two liberal arts colleges in the old New England pattern-and compare the number of scholarships designated for brilliant students in the sciences and social sciences as against brilliant students in the humanities, you would discover a ratio, I think, of no less than twentyfive to one and, very likely, fifty to one. And scholarships no longer represent the full assistance. Since the Second World War, universities have witnessed an extraordinary growth in what is called "contract research," a term that designates a grant, often huge, from a private industry or from government in support of the solution of some special scientific problem: the industry or the government will benefit from the results, but many a young graduate student in science will also benefit as the professor in charge is enabled to employ a whole group of students to staff his laboratory and largely through their experience there earn their advanced degrees. One does not begrudge the science student such benefits, of course, but wishes only to call attention to the fact that nothing comparable is available to the student in humanities, however brilliant. This is at first glance not surprising; at second glance it is, since businessmen themselves today seem to feel that at least a little humanistic experience is a good thing-and so send their successful young men back to college or to institutes where they are expected to expose themselves for a time to those refining graces of the mind that their intensive and exclusive training in business administration or electrical engineering or some special form of industrial chemistry had not earlier permitted. One may guess that it is too late to help form those minds or to reform the values that those minds contain. For, of course, while the humanities are concerned with the transmission of bodies of special information-and it is never too late to learn how Piero della Francesca saw the possibilities of light in painting as none of his predecessors, even Masaccio, had, or what a whimsical letter writer Mozart was and how precisely he constructed a sonata, or how Henry James revised his novels for the New York edition, or who was Heidegger, or what Dylan Thomas really meant by "Man be my metaphor" - while the humanities are, of course, concerned with dispensing such information, that is not their end: their end is the quality of the mind that holds, or even briefly held, that information, and the values that the information, even after it has vanished from that mind, had indestructibly left there.

\section{"Too long a sacrifice}

Can make a stone of the heart,"

said that magnificent humanist, William Butler Yeats, who in his wonderfully oblique way had many fine things to say 
on the subject with which we are dealing. I feel impelled at this point to quote his great poem, "The Leaders of the Crowd"-and I will think of some recent and some current leaders as I read:

"They must, to keep their certainty, accuse

All that are different, of a base intent;

Pull down established honour; hawk for news

Whatever their loose fantasy invent

And murmur it with bated breath, as though

The abounding gutter had been Helicon

Or calumny a song. How can they know

Truth flourishes where the student's lamp has shone,

And there alone, that have no solitude?

So the crowd come, they care not what may come.

They have loud music, hope every day renewed,

And heartier loves; that lamp is from the tomb."'1

And so it is - that lamp: it is our history (history is all a tomb); it is our civilization (much of it rediscovered in tombs by scientists whose work has been or will be explained by humanists or the humanists in themselves); and our selfwhich, strive as it may have through all its time to keep from solitude, arrives there at last, alone, and either knows or does not know why it is there, invited to join history, the perspective of time, into which no intellectual discipline except that of the humanities could have offered the initiation.

Forgive me. I have been amusing myself with poetry, and I have wandered far in this digression that began with the present interest of industry in what $I$

1 The Collected Poems of W. B. Yeats (New York: Macmillan, 1951), p. 182. Reprinted with permission of the publishers. suppose it would call the "well-rounded" junior executive, from my starting point, which was the public recognition of the sciences and the social sciences and the public indifference to the humanities. I had spoken of scholarships for graduate students, of "contract research," and now I would like to mention only one more phenomenon of the same kindgovernment support of academic pursuits. I will not bore you with statistics but only call your attention to the fact that the National Science Foundationthe chief means by which government encourages the teaching and the study of sciences-exists now on a fabulous budget, and that while the private foundations-Guggenheim, Carnegie, Rockefeller, Ford, and so on-do what they can to assist the mature scholar in the humanities (while, generally, assisting those in the sciences with more munificent grants), they can do nothing to help the young, brilliant, but still unproved graduate student, or the aspiring, talented, but still unsung artist.

I, who have been moderately fortunate in this last regard and am grateful, can speak of it without envy. At present I am enjoying the most splendid assistance by which I have yet been honored -a fellowship in the Center for Advanced Study in the Behavioral Sciences, and the solicitation there that attends every possible opportunity to facilitate my research and my more general intellectual interests exceeds every dream of mother love; but I cannot help feeling a little rueful about my good fortune when I consider that the leavening of the literary intelligence is limited (not by stricture, perhaps, but so the fact is) to two of the fifty Fellows-a small cake of yeast in a considerable amount of dough. The Fellows are freed of all academic commitments for a year in order to pursue without interruption their own research. So, at Berkeley, the Miller Institute reduces the teaching load of certain 
scientists and social scientists to pursue theirs. And so it is throughout the country. Does any comparable aid present itself to the humanist? Alas, almost none.

The uneasiness that many a humanist feels about being a humanist is largely the result of the condition that I have tried to sketch. The age, there can be no question, is buying the sciences but is willing, at most, to bargain for the humanities; so the humanist inevitably feels unsure and sometimes shoddy. The most eloquent expression of his uncertainty appears in the invasion of his professional vocabulary by scientific terminology. Words like clinic, laboratory, and in-service, Arthur Minton pointed out seven years ago in the periodical American Speech, are now commonplace in educationist talk. Several years later, in the same journal, Paul Fussell took up the new use of the word interne. "We are"-he wrote- "apparently not soon to be spared the use of interne to mean roughly what 'teaching fellow' has meant heretofore. The New York Times ... carries an article headed 'College Internships' which announces that Vassar College has inaugurated 'a college teacher internship program,' under which 'each interne will have the rank of instructor.' The article continues: 'T he college plans to assign relatively light teaching responsibilities to internes so they may participate in special seminars and inter-departmental conferences.' The writer of the article has plainly missed his opportunity for attaining total consistency: these internes might more effectively have been presented hustling about to special clinics, assiduously comparing findings in interdepartmental laboratories, and even tiptoeing, clipboards in hand, into lying-in, or examination rooms. ... As the odor of ether and green soap ascends over the Vassar campus, we are left with the duty of interpreting this linguistic phenomenon. Mr. Minton suggests that one rea- son for the adoption of these terms by practitioners of non-medical disciplines is that physical science in general and medicine in particular have high prestige.' One feels compelled to speculate that the humanities must be enjoying an alarmingly low prestige in the public eye for humane scholars to feel the need of 'dignifying' their calling by borrowing the most popularly fashionable terms of medical science. . . . we have evidence here of the gradual and continuing decay of the traditional humanist faith in delayed judgments and fondness for the manipulation of forms of moral knowledge involving irreconcilable relativisms and difficult paradoxes. This use of pseudo-medical terms in educational contexts suggests that the liberal arts . . . are continuing to surrender, under pressure, a degree of their humanity and are confusing their liberating function with the scientist's search for empirical fixities and the physician's search for expeditious and positive cures. It is amusing, at any rate, that modern American society should reveal a consciousness of its own intellectual deformities and illnesses through this indiscriminate employment of terms once associated only with the ailing."

But I would ask Mr. Fussell, "Is it amusing? Or is it tragic beyond conjecture?" I would guess the latter at the same time that I would say we need not select Vassar for our abuse. The tendency that this enlightening note suggests may be found everywhere in the humanities. The Library of Congress, I believe, now offers internships to promising librarians. We have a new department of what is presumably humanistic learning called linguistic science. A new fashion in literary scholarship is to apply statistical methods to syntax, vocabulary, and punctuation. And you people, after all, have manufactured a degree called Master of Library Science when, surely, li- 
brarianship can in no remotely accurate sense be associated with what is generally meant by science. "It is a tragedy of contemporary society," wrote Allen Tate, "that so much of democratic social theory reaches us in the language of 'drive,' 'stimulus,' and 'response.' This is not the language of freemen, it is the language of slaves. The language of freemen substitutes for these words, end, choice, and discrimination. Here are two sets of analogies, the one sub-rational and servile, the other rational and free." But science is respectable, and with it, its lingo, and we all seem to feel protected if we can huddle under its flag. "Must we?" the fighting remnant of the humanities demands. "Can one not fly one's own flag, announcing only and always the stature of one?" And many a humanist, harassed, has replied, "No"; his convictions fall with his proper vocabulary. But statistics do not show that, with driver education, motor accidents are fewer, or that, with courses in life adjustment, teen-agers are less delinquent. More important, perhaps, is the fact that fewer and fewer people, in proportion to the number coming off the educational production line, wish to be teachers, and fewest of all, perhaps, teachers of the humanities.

The loss is tragic. Harass us to death and many others will die. I do not think I am being melodramatic; certainly I have no wish to be. Nor am I being only metaphorical, but literal too. Metaphorically, I mean that, for myself at least, it would be like death to exist without some experience of those "life-enhancing values"- to use the phrase of that worthy ancient or ancient worthy, Bernard Berenson-those life-enhancing values that only the arts can give us. It would be the death of the Sinclair Lewis world, where all is grotesque buffoonery, where every individual quality has been sac- rificed to the gray and savage wash of mass conformity. In a new book, Wright Morris contemplates the now famous sentence from William Faulkner's Nobel Prize address, "I believe that man will not merely endure, he will prevail"; and Mr. Morris observes quite properly that these words generate more heat than light. He continues: "More convincingly, it seems to me, Mr. Faulkner also spoke of our fear of annihilation, but $I$ believe it is survival-the wrong kind of survival-that haunts the mind of the artist. It is not fear of the bomb that paralyzes his will-a fear, that is, that man has no future-but, rather, a disquieting and numbing apprehension that such future as man has may dispense with art. With man, that is, such as we know him, and such, for all his defects, as art has made him. It is the nature of the future, not its extinction, that produces in the artist such foreboding, the prescient chill of heart of a world without consciousness."

I have been reminded by my friend, Howard Mumford Jones, to whose substantial thinking on this subject so much of my more flighty generalization is indebted-I have been reminded by him of the pathos-the real emptiness-in the old age of the great Charles Darwin, when he came to regret the "loss of the higher aesthetic tastes": "My mind seems to have become a kind of machine for grinding general laws out of large collections of facts, but why this should have caused the atrophy of that part of the brain alone, on which the higher tastes depend, I cannot conceive. A man with a mind more highly organized or better constituted than mine, would not, I suppose, have thus suffered; and if I had to live my life again, I would have a rule to read some poetry and listen to some music at least once every week; for perhaps the parts of my brain now atrophied would thus have been kept active through use. The loss of these tastes is a loss of happiness, and may possibly be 
injurious to the intellect, and more probably to the moral character, by enfeebling the emotional part of our nature."

Darwin, at least in his youth, enjoyed those "tastes," and in his age he regretted their loss because he knew their value. Today, with the decline of respect for the humanities, most of us are never enabled to enjoy them at all, and therefore we cannot even regret their absence. Most of us today have no experience at all of that great reservoir of $h u$ manitas-to use Roy Harvey Pearce's word from a recent brilliant articlewhich is the treasure house of art. And so most of us have no notion whatever - to quote Roy Pearce again - of "what we could have been if we had not become what we are." This, I declare, is a state of walking death.

Søren Kierkegaard, the theologian and forerunner of existentialism, said that "The task of the human being is to become what he already is." Really, only more positively, he was saying what Professor Pearce says. All that a human being can aspire to, he meant, is the development of his humanity. To deny one's own human potentialities the right to growth, whether through laziness or apathy or practicality or stupidity or fright - to deny what comprises, in fact, the greatest part of one's human potentialities, is in effect to murder them. This is the great modern mass suicide. In a mood of mystical reverie, one of D. H. Lawrence's heroines mused with frightening foresight, "And would the great negative pull of the Americas at last break the heart of the world? ... Charmless America! With your hard, vindictive beauty, are you waiting forever to smite death? Is the world your everlasting victim?"

Lawrence brings us, then, to the literal consideration of death. Some years ago Alfred North Whitehead-another great humanistic scientist-pointed out what we all know today: that our scientific knowledge, especially in the area where science is applicable to warfare-and where is it not?-has far outstripped our moral and our social intuitions. We have developed instruments of destruction that we are apparently without power to control. The social and moral intuitions are not developed in cyclotrons or through the intricate operations of statistical computers: they are developed only through a continuing exposure of individual intelligence to the history of civilization, are maintained only through the continuing capacity of individuals to identify themselves with that history. Only the humanities can provide the opportunities. And I will go further and say that since only the humanities, of the several disciplines, enable the individual to identify himself with the history of civilization, only the humanities can preserve civilization.

The immediate problem was dramatically illustrated only a few months ago by the request of the new French government that it be assisted in the manufacture of atomic weapons-and the announcement that it would manufacture them, with or without assistance - a perfectly justified demand, let me say. Since the end of the Second World War, in the armed truce that exists between this country and Russia, it has been the hope of military men to maintain a balance of power through the accelerating efforts of scientists. But now we face that prospect of seeing such a balance to be the impossible thing that it is, as small nations become as powerful as the greatest. Last summer in Geneva military men and scientists gathered to discuss the whole nightmare situation, and now politicians have gathered to carry on from those discussions, but when the frame of reference shifts from technique to policy, the implausibility of remedy becomes apparent. We have reached the extremity - the real extremity, the issue between civilization (Continued on page 134) 


\section{The Harassed Humanities}

(Continued from page 110)

preserved and extinction-the real extremity where only another kind of intelligence can effectively work. Military security can no longer be preserved by military or by scientific means. There is only one other means. We need the thinking of humanistic scientists, or, if you will, of humanists; we need the humanities. We need the man who speaks not only his own language, but the universal language of creative responsibility. And how simply one can illustrate: while the Russian embassy, seat of political power, was the scene of violent rioting in Washington, the Moiseyev dancers were performing before packed auditoriums throughout the country and young Van Cliburn had just returned from his spectacular triumph in Moscow; again, just after Richard Nixon was stoned by indignant mobs in Caracas, the San Francisco Ballet Company repeatedly performed, in that same city, to overflow audiences whose enthusiastic demands it could not meet because of a touring schedule. There is a language, a greater language than that of politics or statistics or cold but killing formulae, a language that all men speak and understand: it is the language of human culture. We have never needed to hear that language so desperately as we need to hear it today in the councils of power. But to give it voice, we must first supply Mr. Nixon, Mr. Dulles, and many others, with an education in the humanities. If any one of you wishes to suggest a curriculum, you can reach these worthies at either Number One Madison Avenue or Number One Main Street. The addresses designate the same place.

How beautifully W. B. Yeats put it: "The artist loves above all life at peace with itself." It could not be otherwise, for his function, after all, is the creation of harmonies and unities, those monuments of unaging intellect that comprise the order of civilization and preserve it for us to carry on. In the last analysis, what other study is worth our time? William Blake told us why: "Where Man Is Not, Nature Is Barren."

\section{The Book in the USSR}

It can safely be said that the book has played an outstanding part in the cultural revolution accomplished in the USSR. Being accessible to the people, becoming part and parcel of the Soviet man's everyday life, the book is now a thing of prime necessity.

Statistics on book publishing and sales are usually a fairly reliable index of the cultural, and even of the scientific, development of a nation. One may guess that there is a correlation of considerable significance between the large circulation of books and so advanced a scientific achievement as the launching of the first earth satellites.-Yuri Gvosdev, Assistant Commercial Counselor of the Embassy of the Union of Soviet Socialist Republics, in Iron Curtains and Scholarship: The Exchange of Knowledge in a Divided World, Papers Presented before the Twenty-Third Annual Conference of the Graduate Library School of the University of Chicago, July 7-9, 1958, ed. by Howard W. Winger (Chicago: 1958), p.43. 